\title{
IMPLEMENTATION OF ACTIVE, CREATIVE AND FUN LEARNING (PAKEM) AND MOTIVATION IN IMPROVING STUDENT LEARNING OUTCOMES
}

\section{Imam Santoso and Winner Saragih}

STIMA IMMI Jakarta

E-mail: santosoimam243@ gmail.com,wsaragih153@yahoo.com

\begin{tabular}{ll}
\hline ARTICLE INFO & ABSTRACT \\
\hline Received: & The purpose of this study was to determine the effect of
\end{tabular}

July, 24 2021

Revised:

August, 9th 2021

Approved:

August, 13 ${ }^{\text {th }} 2021$
The purpose of this study was to determine the effect of PAKEM (active, creative and fun learning) and learning motivation on student learning outcomes in science subjects at 31 State Junior High Schools in Tangerang City. This study uses a quantitative approach, descriptive and associative types. The population in this study was 554 students. The sampling technique used in this study is the Slovin formula. By using the slovin formula technique, a sample of 41 students of 31 Tangerang City Junior High School was taken as respondents in this study. The results of this study indicate that: 1) the tcount value for $X 1$ (Active, Creative and Fun Learning)) is 5,831 while the ttable value for $n=41$ is 2,020. So 5,831 > 2,020, Can Key partially affect student learning outcomes. 2) the $t$-count value for the $X 2$ variable (Learning Motivation) is 3.399, while the ttable value for $n=41$ is 2,020. So $3.399>2.020$, the key can be partially that Learning Motivation has an effect on Student Learning Outcomes. 3) ANOVA test or Ftest or Fcount obtained a value of 39.815 which is greater than Ftable of 2.83 or $39.815>2.83$ with a significant level of 0.000 because $0.000<0.05$, it can be said that the Pakem variable (Active, Creative and Fun Learning) (X1) and the variable of Learning Motivation (X2) together have an effect on the variable of Student Learning Outcomes

\begin{tabular}{ll}
\hline & Imam Santoso and Winner Saragih. (2021). Implementation Of Active, \\
& Creative And Fun Learning (Pakem) and Motivation In Improving Student \\
& Learning Outcomes. Journal Eduvest. 1(8): 667-67 \\
How to cite: & $2775-3727$ \\
E-ISSN: & https://greenvest.co.id/
\end{tabular}


(Y).

\begin{tabular}{ll}
\hline KEYWORDS & Pakem, Learning Motivation, Student Learning Outcomes \\
\hline (c) (i) (O) & This work is licensed under a Creative Commons \\
\hline
\end{tabular}

\section{INTRODUCTION}

Science is a subject that is considered difficult by most students, from elementary to high school levels, and the quality of science education in Indonesia, in terms of NEM scores, is still apprehensive (Hastuti \& Budianti, 2014). The higher the education level, the smaller the average NEM of science or science students gets. This is of course very concerning, even though many efforts have been made, both by the government, the private sector and teachers. These efforts include funds, time, energy, and thoughts that have been devoted to improving the quality of science education, but have not produced satisfactory results.

The Active, Creative, Effective and Fun Learning Model (PAKEM) enables students to do various activities to develop skills, attitudes and understanding of various sources and learning aids, including the use of the environment (Fahmi, 2013). Although the expected activity and creativity of students, but actually teachers are required to be active and creative (Ma'aruf, 2009).

PAKEM emphasizes the active involvement of students in the learning process so that students can gain hands-on experience and are trained to be able to discover the various knowledges they learn for themselves. Through direct experience students will understand the concepts they are learning and relate them to other concepts that they have understood (Ahmadi \& Amri, 2011).

One solution that can make students more active and creative is to improve the quality of the learning process. According to (Moh Uzer usman, 2011), the teaching and learning process is the core of the overall educational process with the teacher as the main role holder.

PAKEM allows students and teachers to be actively involved in learning (Khoiriyah, 2019). So far, conventional learning models are considered only active (monological) teachers, while students are passive, so learning is considered boring, less interesting and unpleasant. PAKEM allows both students and teachers to be creative. Teachers try to be creative in trying various ways to involve all their students in learning. Meanwhile, students are also required to be creative in interacting with friends, teachers, and teaching materials with all the tools.

PAKEM is a learning strategy to develop students' skills and understanding, with an emphasis on learning by doing. In order to achieve the learning objectives that have been set in the curriculum, teachers need a series of learning activities, starting from planning, determining strategies, selecting learning materials and methods to assessment. In addition, it is necessary to have motivation both within students and teachers, so that it can generate student learning which in turn can improve student achievement (Widhy, 2010).

In the implementation of PAKEM there are several things that must be considered, namely understanding the nature of the child; take advantage of children's behavior in organizing learning; develop critical thinking, creative, and problem solving skills; develop the classroom as an attractive environment; utilizing the environment as a learning resource; provide good feedback to improve learning activities; distinguish between physically active and mentally active (Fatmah, Jumadi, \& Junda, 2018). 
The eight things above that teachers must pay attention to in the process of implementing PAKEM in the classroom. Teachers must continue to practice developing abilities in carrying out these eight things. Teachers should not be easily angered, and discouraged, because all success requires intensive and extractive practice and consistency.

Science learning models in schools that are still far from established or less innovative can be viewed from the quality of teaching that is still manual, and this is one aspect of the assessment that requires changes and then developed with active, effective and fun teaching methods (grip). This is where the important role of science teachers is to introduce as well as actors in the effort to introduce learning through teaching that is easily accepted by students.

Active learning is a learning process in which a teacher must be able to create an atmosphere in such a way that students actively ask, question and express their ideas (Nandar \& Indrapraja, n.d.). This student activity is very important to form a creative generation, which is able to produce something for the benefit of himself and others. While the learning process is fun, this is closely related to a pleasant learning atmosphere so that students can focus their attention fully on their learning. This requires the creativity of the teacher to be able to liven up the teaching and learning atmosphere so that it is not boring for the students.

This learning will be achieved by developing the ability to think critically, creatively with the ability to be able to solve problems. Developing the classroom as an environment interesting learning, utilizing the environment as a learning resource for students and providing good feedback between students and teachers, to be able to improve learning activities (Nurasiah, 2018). In addition, teachers are also expected to be able to distinguish between physically active and mentally active students. Many teachers are satisfied when they see their student busy working, but sometimes these students are not mentally active, or are afraid to ask questions and also express their ideas. Therefore, the teacher should eliminate the cause of fear and try to improve the mentality of the students in the learning process.

On the other hand, in addition to the importance of knowledge of standard methods, active also said that the sharpening of abilities in the field of research (research) in religious education should not be ruled out. Therefore, information and accurate strategies in managing research are important as materials for self-development for science teachers in their efforts to improve student learning outcomes, especially in science subjects.

In addition, factors that affect learning achievement is the motivation of students themselves. It is often found that students have high intelligence but low student achievement, due to their intellectual abilities not functioning optimally or not. One of the supporting factors so that students' intellectual abilities can function optimally is the high motivation to learn in them. According to Tambun in (Ariani, 2014), "motivation is a psychological condition that encourages someone to do something. In teaching and learning activities, motivation can be said as the overall driving force in students that creates, ensures continuity and provides direction for learning activities, so that it is hoped that the goals can be achieved. Students will study seriously without being forced, if they have high learning motivation, they will achieve high achievement as well. The existence of high learning motivation in students will encourage students to learn on their own and overcome various learning difficulties.

Learning outcomes are all changes in the cognitive, affective and psychomotor fields and cause humans to change in attitudes and behavior (Winkel, in Setiyowati, 2009). Talking about the quality of education cannot be separated from learning 
Imam Santoso and Winner Saragih

activities. The expected result of learning activities is good learning achievement. Everyone certainly craves high learning achievement, both parents, students, and even more so for teachers. To achieve optimal learning achievement can not be separated from the conditions where the possibility of students can learn effectively and can develop the power of exploration. 
Getting good learning achievement is not easy, many factors influence, these factors include teachers, parents and students. According to (Pandi, Rosadi, \& Jaya, 2021), student factors play an important role in achieving learning achievement, because students who carry out learning activities need to have study perseverance, high achievement motivation, good learning discipline, and participate in the implementation of learning.

According to (Rini, 2003), "learning achievement is the mastery of knowledge or skills developed by subjects, usually indicated by test scores or scores given by the teacher". In Indonesia, the measuring instrument for evaluating learning achievement is called a learning outcome test. These two tests are used to measure the level of success of a teaching program and to find out to what extent students have utilized their cognitive abilities. The success of the teaching and learning process is the main thing that is desired in the implementation of education in schools. The purpose of the learning process is to obtain optimal results through optimizing the learning process, it is hoped that students can achieve optimal and satisfying learning achievements. The success or failure of learning is marked by the learning achievement achieved by a person in a learning effort. The teaching and learning process must be interactive, educative and active between the two factors, especially the teacher factor and the way of teaching or the teacher's competence and the student motivation factor. Teaching and learning activities of students will give an appreciation of all attitudes and teaching behavior carried out by a teacher. Each student has a different perception in looking at the extent to which a teacher has the ability to teach.

However, in fact according to (Septianto, 2012) "learning achievement shows that there are still many students who get low learning achievement. Especially when it is associated with the needs and demands of society. Common symptoms that occur with learning outcomes that arise are the low quality of student learning activities such as lack of preparation, the presence of students who want to achieve the target just passing in schools, there are students who think that the learning outcomes they get depend on fate and not effort and hard work. If these problems are left unchecked, the further impact is that the quality of education and human resources is low, causing the effect of low learning outcomes obtained by students.

\title{
RESEARCH METHODS
}

This study uses a quantitative approach using descriptive and associative research types. In this study, the population studied were 554 students at the 31 st State Junior High School in Tangerang City. The sampling technique used in this study is the Slovin formula. By using the slovin formula technique, a sample of 41 students of 31 Tangerang City Junior High School was taken as respondents in this study.

\section{RESULTS AND DISCUSSION}

\author{
A. Data Analysis Results \\ 1. T-test
}

Table 1 T-test result

\begin{tabular}{lcrc}
\hline Coefficients $^{\mathrm{a}}$ & & & \\
\hline Model & $\begin{array}{c}\text { Unstandardized } \\
\text { Coefficients }\end{array}$ & $\begin{array}{c}\text { Standardi } \\
\text { zed Coefficients }\end{array}$ & Sig. \\
\hline
\end{tabular}




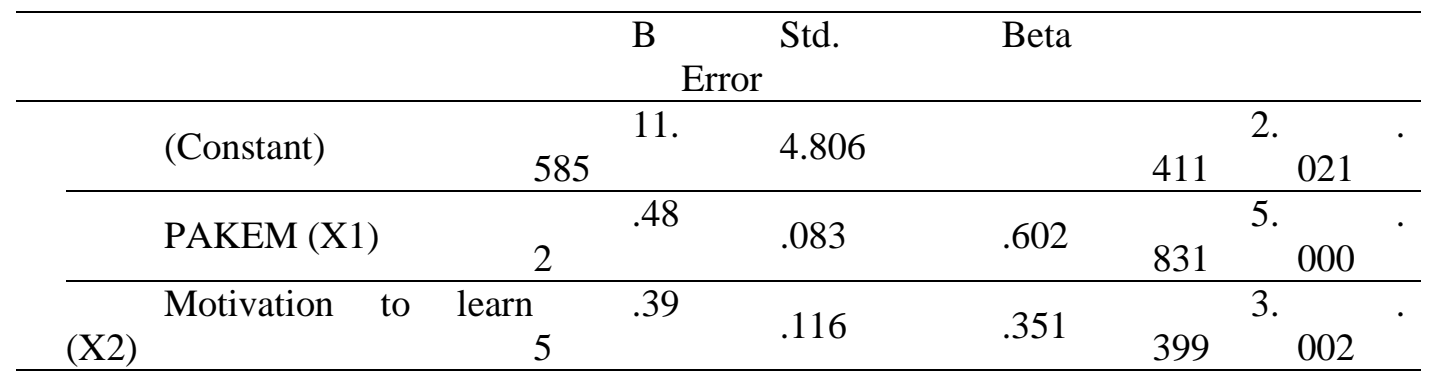

a. Dependent Variable: Student Learning Outcomes (Y)

The tcount value for the X1 variable (Package (Active, Creative and Fun Learning)) is 5,831 while the ttable value for $n=41$ is 2,020. So 5,831 >2020, it can be concluded that partially the Pakem variable (Active, Creative and Fun Learning) has an effect on Student Learning Outcomes. Probability value (significance) $=0.000$. So the probability is 0.000 under 0.05 . Thus, $\mathrm{H} 0$ is rejected and Ha accepts, it can be concluded that there is a positive and significant effect between the $\mathrm{X} 1$ variable and the $\mathrm{Y}$ variable, because the probability value is smaller than 0.05 .

2. F-test

Table 2 F-test Result

\begin{tabular}{|c|c|c|c|c|c|}
\hline \multicolumn{6}{|l|}{ ANOVA $^{\mathrm{a}}$} \\
\hline \multirow[b]{2}{*}{ Model } & Sum & \multicolumn{3}{|c|}{ Mean } & \multirow[b]{2}{*}{ Sig. } \\
\hline & Squares & df & Square & $\mathrm{F}$ & \\
\hline Regressi & 2589.429 & 2 & 1294.715 & 39.81 & $.000^{\mathrm{b}}$ \\
\hline \multirow[b]{2}{*}{ Residual } & & \multicolumn{3}{|c|}{5} & \\
\hline & 1235.693 & 38 & 32.518 & & \\
\hline Total & 3825.122 & 40 & & & \\
\hline a. Dependen & t Variable: Studen & rnin & Outcomes (Y) & & \\
\hline b. Predictors & : (Constant), Moti & $\mathrm{n}$ to & $\operatorname{arn}(\mathrm{X} 2)$, PAKEN & & \\
\hline
\end{tabular}

From the results of the table above, namely the ANOVA test or Ftest or Fcount, a value of 39,815 is obtained which is greater than Ftable of 2.83 or $39,815>2.83$ with a significant level of 0.000 because $0.000<0.05$, it can be said that the Pakem variable (Active, Creative Learning) and Fun) (X1) and the variable of Learning Motivation (X2) together have an effect on the variable of Student Learning Outcomes (Y).

3. Model Summary

Table 3 Model Summary ${ }^{\mathrm{b}}$

\begin{tabular}{|c|c|c|c|c|}
\hline Model & $\mathrm{R}$ & R Square & Adjusted & $\begin{array}{l}\mathrm{R} \text { Std. Error of the } \\
\text { Estimate }\end{array}$ \\
\hline 1 & $.823^{\mathrm{a}}$ & .677 & .660 & 5.70248 \\
\hline
\end{tabular}

a. Predictors: (Constant), Motivation to learn (X2), Pakem (X1)

b. Dependent Variable: Student Learning Outcomes (Y)

Source: Questionnaire Data Compilation, 2019 
Based on the Model Summary table, the R Square value is 0.677. This shows that $67.7 \%$ of Pakem (Active, Creative and Fun Learning) and Learning Motivation simultaneously (together) have an effect on Student Learning Outcomes, while the remaining $32.3 \%$ is influenced by other factors not examined in this study.

\section{B. Discussion}

\section{The Effect of Standards on Student Learning Outcomes}

There is an influence of Pakem (Active, Creative and Fun Learning) on Student Learning Outcomes, as evidenced by the tcount value for the X1 variable (Pakem (Active, Creative and Fun Learning)) of 5,831 while the ttable value for $\mathrm{n}=41$ is 2,020. So 5,831 $>2020$, it can be concluded that partially the Pakem variable (Active, Creative and Fun Learning) has an effect on Student Learning Outcomes.

PAKEM is a strategy that allows students to work on a variety of activities to develop their skills, attitudes, and understanding with an emphasis on learning by doing. Meanwhile, teachers use various sources and learning aids, including the use of the environment, so that learning is more interesting, fun, and effective.

In PAKEM, the principles of competency-based learning are used. This computerbased learning is learning that is carried out with the orientation of achieving student competence. In Permendiknas number 41 of 2007 concerning process standards, it is also mandated that core learning activities must also be fun, challenging, motivate students to participate actively, and provide sufficient space for initiative, creativity, and independence according to their talents, interests, and abilities. physical and psychological development of students. This learning activity is carried out systematically and systemically through a process of exploration, elaboration, and confirmation. So, legally, standard-based learning has become a must in learning at school.

PAKEM is a learning model that is based on 4 principles, namely active, creative, effective and fun. Active means that in the learning process the teacher must create an atmosphere in such a way that students actively ask questions, question and express opinions or ideas. The active role of students is very important in the context of forming a creative generation that is able to produce something for the benefit of themselves and others.

In this case, a teacher must be able to take advantage of the learning modalities that students have, both visual, auditory and kinesthetic, so that learning can be optimal and students are actively involved directly in learning. Creative is intended so that teachers create diverse learning activities, so as to meet various levels of students' abilities. The word creative can also be interpreted to foster motivation, confidence and criticalness, so that learning is not monotonous and full of creativity. Effective means taking advantage of the available time. In the learning process must be in accordance with the learning planning that has been designed. Fun is a fun teaching and learning atmosphere. Fun learning can be seen from the attractive appearance of the teacher, an active learning atmosphere, rich in learning methods, class design that is not boring, so that students focus their attention fully on learning time and the time for students' attention to learning becomes high. An active and pleasant state is not enough if the learning process is not effective, because learning has a number of learning objectives that must be achieved. On the other hand, if learning is only active and fun but not effective, then the learning is like playing ordinary games.

Based on the understandings of learning outcomes above, it can be concluded that PAKEM is learning that allows students to carry out various activities to develop skills, attitudes and understanding by prioritizing learning while working, teachers use various learning resources and aids including the use of the environment as a learning resource so that learning is more interesting, fun and effective. 


\section{The Effect of Learning Motivation on Student Learning Outcomes}

There is an effect of learning motivation on student learning outcomes, as evidenced by the tcount value for the X2 variable (Learning Motivation) of 3.399, while the ttable value for $n=41$ is 2,020. So $3.399>2.020$, it can be concluded that partially the variable of Learning Motivation has an effect on Student Learning Outcomes.

Motivation is the process that gives enthusiasm, direction, and persistence to behavior. That is, behavior that has motivation is behavior that is full of energy, directed, and lasts a long time (Santrock, 2007).

Learning motivation is an encouragement from the learning process in other words the purpose of learning is to get good results. Many students have problems in learning as a result the learning outcomes achieved are low. To overcome this, it is necessary to explore the factors that influence learning outcomes, especially student learning motivation. Learning motivation is an absolute requirement for learning. And plays an important role in providing passion or enthusiasm for learning. Euis Karwati and Doni Juni Priansa (2015:167) say that learning motivation is a process that shows the intensity of students in achieving the direction and goals of the learning process they are experiencing.

Meanwhile, Eko Putro Widoyoko (2012: 234) says that motivation is a condition that arises in individuals caused by the interaction between motives and events observed by individuals, thus encouraging activating behavior into real action. Motivation is a conscious effort to influence a person's behavior so that he is moved to act to do something so as to achieve certain results or goals (Purwanto, 2011).

Motivation is needed by students to implement strategies that will affect the learning process. Learning motivation makes students more efficient in managing time and effective in learning. According to Hamzah B. Uno (2011:23) the nature of learning motivation is internal and external encouragement for students who are learning to make changes in behavior, generally with several indicators or supporting elements.

Motivation comes from the word motive which means an encouragement that is directed towards psychological and spiritual fulfillment. According to Mc. Donald (Oemar Hamalik, 2011:106), motivation is a change in energy in a person (personal) which is characterized by the emergence of feelings and reactions to achieve goals. Meanwhile, according to Sardiman A. M in learning activities motivation can be said as the overall driving force in students that causes learning activities, so that the goals desired by the learning subject can be achieved.

\section{The Influence of Practice and Motivation to Study Together on Student Learning Outcomes}

There is an influence of Pakem (Active, Creative and Fun Learning) and Learning Motivation together on Student Learning Outcomes, as evidenced by the ANOVA or Ftest or Fcount tests that get a value of 39.815 which is greater than Ftable of 2.83 or $39.815>2.83$ with a significant level of 0.000 because $0.000<0.05$, it can be said that the Pakem variable (Active, Creative and Fun Learning) (X1) and Learning Motivation variable (X2) jointly affect the Student Learning Outcome variable (Y). While the value of R Square is 0.677. This shows that $67.7 \%$ of Pakem (Active, Creative and Fun Learning) and Learning Motivation simultaneously (together) affect Student Learning Outcomes, while the remaining $32.3 \%$ is influenced by other factors not examined in this study.

Learning outcomes are the most important part of learning. Nana Sudjana (2009:3) defines student learning outcomes in essence as changes in behavior as a result of 
learning in a broader sense covering the cognitive, affective, and psychomotor fields.

Learning outcomes show the actual abilities of students who have experienced the process of transferring knowledge from someone who can be said to be an adult or has less knowledge (Purwanto, 2010:42). So with the learning outcomes, people can find out how far students can catch, understand, have certain subject matter. On that basis, educators can determine better teaching and learning strategies.

Learning outcomes are the ultimate goal of implementing learning activities in schools. Learning outcomes can be improved through conscious efforts that are carried out systematically leading to positive changes which are then called the learning process. The end of the learning process is the acquisition of student learning outcomes. Student learning outcomes in class are collected in the set of class learning outcomes. All of these learning outcomes are the result of an interaction of act of learning and act of teaching. From the teacher's side, the act of teaching ends with the process of evaluating learning outcomes, while from the student's side, learning outcomes are the end of the cut and the peak of the learning process (Dimyati and Mudjiono, 2013: 3).

\section{CONCLUSION}

Based on the results of the analysis and discussion, the authors conclude that there is an influence of Pakem (Active, Creative and Fun Learning) on Student Learning Outcomes, as evidenced by the tcount value for the X1 variable (Pakem (Active, Creative and Fun Learning)) of 5,831 while the t-table value for $n=41$ of 2,020. So 5,831>2020, it can be concluded that partially the Pakem variable (Active, Creative and Fun Learning) has an effect on Student Learning Outcomes. There is an effect of learning motivation on student learning outcomes, as evidenced by the tcount value for the $\mathrm{X} 2$ variable (Learning Motivation) of 3.399, while the ttable value for $\mathrm{n}=41$ is 2,020 . So $3.399>2.020$, it can be concluded that partially the variable of Learning Motivation has an effect on Student Learning Outcomes. There is an influence of Pakem (Active, Creative and Fun Learning) and Learning Motivation together on Student Learning Outcomes, as evidenced by the ANOVA or Ftest or Fcount tests that get a value of 39.815 which is greater than Ftable of 2.83 or $39.815>2.83$ with a significant level of 0.000 because $0.000<0.05$, it can be said that the Pakem variable (Active, Creative and Fun Learning) (X1) and Learning Motivation variable (X2) jointly affect the Student Learning Outcome variable (Y). While the value of $R$ Square is 0.677 . This shows that $67.7 \%$ of Pakem (Active, Creative and Fun Learning) and Learning Motivation simultaneously (together) affect Student Learning Outcomes, while the remaining $32.3 \%$ is influenced by other factors not examined in this study.

\section{REFERENCES}

Ahmadi, Iif Khoiru, \& Amri, Sofan. (2011). Mengembangkan Pembelajaran Ips Terpadu. Jakarta: Prestasi Pustaka.

Ariani, Marina Dwi. (2014). Penggunaan Media Pembelajaran Dan Motivasi Belajar Terhadap Prestasi Belajar Ips Ekonomi Pada Siswa Kelas Viii Smp Muhammadiyah Purwodadi Tahun Ajaran 2014/2015. Universitas Muhammadiyah Surakarta.

Fahmi, Zul. (2013). Indikator Pembelajaran Aktif Dalam Konteks Pengimplementasian Pendekatan Pembelajaran Aktif, Kreatif, Efektif, Dan Menyenangkan (Pakem). AlTa Lim Journal, 20(1), 278-284.

Fatmah, Andi Nurul, Jumadi, Oslan, \& Junda, Muh. (2018). Pengaruh Strategi Paikem (Pembelajaran Aktif, Inovatif, Kreatif, Efektif, Menyenangkan) Terhadap Motivasi 
Dan Hasil Belajar Siswa. Seminar Nasional Biologi.

Hastuti, Ari, \& Budianti, Yudi. (2014). Pengaruh Penggunaan Media Audio Visual Terhadap Hasil Belajar Siswa Pada Mata Pelajaran Ipa Kelas Ii Sdn Bantargebang Ii Kota Bekasi. Pedagogik (Jurnal Pendidikan Sekolah Dasar), 2(2), 33-38.

Khoiriyah, Khoiriyah. (2019). Peningkatan Hasil Belajar Ipa Materi Konduktor Dan Isolator Panas Melalui Model Pakem Pada Siswa Kelas Vi Sdn Sugihwaras Kabupaten Sidoarjo. E-Jurnal Mitra Pendidikan, 3(6), 838-852.

Ma'aruf, Zuhdi. (2009). Implementasi Pembelajaran Aktif Kreatif Efektif Dan Menyenangkan (Pakem) Untuk Pendidikan Sains Di Sekolah. Jurnal Geliga Sains: Jurnal Pendidikan Fisika, 3(2).

Moh Uzer Usman. (2011). Menjadi Guru Professional. Bandung: Remaja Rosdakarya.

Nandar, Ismu, \& Indrapraja, Diecky Kurniawan. (N.D.). Peningkatan Hasil Belajar Siswa Dalam Menyanyikan Lagu Seriosa Dengan Model Pakem Di Smp. Jurnal Pendidikan Dan Pembelajaran Khatulistiwa, 4(1).

Nurasiah, St. (2018). Peningkatan Minat Belajar Sains Melalui Metode Pembelajaran Pakem (Pembelajaran Aktif, Kreatif, Efektif Dan Menyenangkan) Siswa Kelas Iii Min 2 Makassar. Universitas Islam Negeri Alauddin Makassar.

Pandi, M.Dwi, Rosadi, Kemas Imron, \& Jaya, Jaya. (2021). Peran Orang Tua Dalam Meningkatkan Motivasi Belajar Anak Dengan Sistem Daring Pada Pendidikan Agama Islam Desa Limau Manis Kecamatan Kemuning Kabupaten Inhil Provinsi Riau. Uin Sulthan Thaha Saifuddin Jambi.

Rini, Jeane. (2003). Hubungan Antara Persepsi Orang Tua Tentang Prestasi Belajar Dengan Prestasi Belajar Anak Sekolah Dasar. Yogyakarta: Pustaka Pelajar.

Septianto, Saya Indra Wachid. (2012). Persepsi Siswa Mengenai Kompetensi Guru Dan Penggunaan Media Pembelajaran Terhadap Prestasi Belajar Siswa Pada Mata Pelajaran Ips Ekonomi Siswa Kelas Viii Di Smp Negeri 02 Gatak Sukoharjo Tahun Ajaran 2011-2012. Universitas Muhammadiyah Surakarta.

Setiyowati, Anik. (2009). Pengaruh Penerapan Pakem Melalui Pendekatan Ibl Terhadap Hasil Belajar Materi Pokok Kelarutan Dan Hasil Kali Kelarutan. Universitas Negeri Semarang.

Widhy, Purwanti. (2010). The Six Thinking Hats Sebagai Upaya Peningkatan Pembelajaran Ipa Yang Pakem. Majalah Ilmiah Pembelajaran, 8(2). 